\title{
Pengaruh penggunaan limbah cair pemindangan ikan dalam ransum terhadap lemak daging dan lemak abdominal itik persilangan Mojosari Peking
}

\section{The effect of the use of liquid waste boiled salt fish in ration on cholesterol meat and abdominal fat of Mojosari Peking crossing duck}

\author{
Shafry Imtiyaz*, Luthfi Djauhari Mahfudz dan Dwi Sunarti \\ Fakultas Peternakan dan Pertanian Universitas Diponegoro Semarang \\ Tegalsari, Srigading, Sanden, Bantul, 55763, Indonesia
}

Submitted : 25 September 2017, Accepted : 30 October 2017

\begin{abstract}
ABSTRAK : Tujuan dari penelitian ini adalah untuk mengkaji pengaruh penggunaan limbah cair pemindangan ikan dalam ransum terhadap kadar lemak daging, persentase lemak abdominal serta kadar kolesterol itik hasil persilangan Mojosari Peking. Materi yang digunakan adalah itik hasil persilangan Mojosari Peking jantan umur 3 minggu sebanyak 120 ekor dengan bobot badan rata - rata 520,30 $\pm 57,82$ g. Rancangan penelitian menggunakan rancangan acak lengkap (RAL) dengan 4 perlakuan dan 5 ulangan. Terdapat 20 unit percobaan yang terdiri terdiri dari 6 ekor itik tiap unit. Perlakuan yang diterapkan adalah limbah cair pemindangan ikan dengan level: $\mathrm{T} 0=0 \%, \mathrm{~T} 2=2,5 \%, \mathrm{~T} 3=5 \%$ dan $\mathrm{T} 4=7,5 \%$. Hasil penelitian menunjukkan bahwa penggunaan limbah cair pemindangan ikan tidak memberikan pengaruh nyata $(\mathrm{P}>0,05)$ terhadap persentase lemak daging, persentase lemak abdominal dan kadar kolesterol daging. Berdasarkan hasil penelitian dapat disimpulkan bahwa penggunaan limbah cair pemindangan ikan dalam ransum hingga taraf 7,5\% belum mampu menurunkan persentase lemak daging, persentase lemak abdominal dan kadar kolesterol itik.
\end{abstract}

Kata kunci : limbah cair pemindangan ikan, itik, lemak, kolesterol

\begin{abstract}
This research's intention was to examined the effect of liquid waste boiled salt fish in the ration on fat and cholesterol meat and abdominal fat percentage of Mojosari Peking crossing duck. The research materials used were 120 of 3 weeks old males Mojosari Peking duck crossing with average initial body weight of $520.30 \pm 57.82 \mathrm{~g}$. This experimental design was used completely randomized design (CRD) with 4 treatments and 5 replications with total 20 units experimental each unit consisted of 6 ducks. The treatment used of liquid waste boiled salt fish in rations with level: $\mathrm{T} 0=0 \%, \mathrm{~T} 2=2.5 \%, \mathrm{~T} 3$ $=5 \%$ dan $\mathrm{T} 4=7.5 \%$. The results showed that the the used of liquid waste boiled salt fish have no significant effect $(\mathrm{P}>0,05)$ on fat meat, abdominal fat percentage and cholesterol meat. The used of of liquid waste boiled salt fish can be used in the ration up to the level $7.5 \%$.
\end{abstract}

Keywords : liquid waste boiled salt fish, duck, fat, cholesterol

\footnotetext{
${ }^{*}$ Corresponding author: shafry.imtiyaz@ gmail.com
} 


\section{PENDAHULUAN}

Itik merupakan unggas air yang dipelihara sebagai penghasil telur dan daging. Peran itik sebagai penyedia daging pada tahun 2016 adalah sebesar 36.350 ton (Ditjennak, 2016). Itik memiliki kandungan lemak yang tinggi pada kulit yang berperan sebagai isolator terhadap dingin karena itik juga merupakan unggas air. Namun, kandungan lemak yang tinggi pada itik menyebabkan masyarakat kurang menyukai mengonsumsi daging itik karena dikhawatirkan dapat memicu penyakit. Salah satu sumber deposit lemak daging berasal dari pakan oleh karena itu dibutuhkan ransum dengan bahan yang dapat menekan timbunan lemak tersebut salah satunya adalah asam lemak tak jenuh Limbah cair pemindangan ikan merupakan hasil sampingan perebusan ikan dengan tujuan pengawetan ikan. Limbah cair pemindangan ikan mengandung nutrisi antara lain protein $0,32 \%$, lemak $10,95 \%$ dan kadar air 83,45\%. Lemak yang terdapat dalam limbah tersebut diduga terdapat minyak ikan khususnya asam lemak esensial yang didalamnya terdapat Poly Unsaturated Fatty Acid (PUFA) atau asam lemak tak jenuh. PUFA mengandung asam lemak omega 3 yang merupakan asam lemak esensial.

$\begin{array}{ccr}\text { Omega-3 dapat menekan } & \text { melalui } \\ \text { pembentukan } & \text { lemak } & \text { melal }\end{array}$
penghambatan biosintesis kolesterol yang dengan sendirinya menekan aktivitas VLDL yang merangsang pembentukan lipida darah. Omega 3 menghambat biosintesis kolesterol dengan menghambat aktivasi Hidroksi Metil Glutaril Asetil KoA (HMG KoA) reduktase dan piruvatkinase (Chasnhidel dkk., 2009). HMG KoA reduktase adalah enzim utama yang mendukung sintesis kolesterol dalam hati dengan berikatan dengan mengubah HMG KoA menjadi mevalonat. Asetil Ko A merupakan substrat untuk sintesis kolesterol (Montgomery et al., 1993). Rendahnya VLDL akan menyebabkan hati lebih banyak merubah kolesterol menjadi empedu yang akan meningkatkan aktivitas reseptor HDL sehingga kolesterol menurun dan pembentukan lemak di dalam tubuh ternak juga menurun.

Tujuan penelitian adalah untuk mengkaji pengaruh penggunaan limbah cair pemindangan ikan sebagai campuran ransum terhadap lemak daging, persentase lemak abdominal dan kolesterol daging itik persilangan Mojosari Peking pada fase pertumbuhan.

\section{MATERI DAN METODE}

Penelitian ini dilaksanakan dilaksanakan pada bulan Maret 2017 sampai Mei 2017 bertempat di kandang unggas Fakultas Peternakan dan Pertanian Universitas Diponegoro, Semarang. Materi yang digunakan dalam penelitian yaitu itik hasil persilangan Mojosari Peking jantan umur 3 minggu sebanyak 120 ekor dengan rincian 4 perlakuan dan 5 ulangan, setiap ulangan berisi 6 ekor itik yang dipilih dengan bobot badan rata - rata sebesar 520,30 \pm 57,82 g. Limbah cair pemindangan ikan yang digunakan diperoleh dari industri pemindangan ikan di Desa Bajomulyo, Kecamatan Juwana, Kabupaten Pati. Ransum untuk itik umur 3-8 minggu terdiri dari konsentrat CP 144, jagung dan bekatul. Kandungan nutrisi bahan pakan berdasarkan sumbernya dapat dilihat dalam Tabel 1. Komposisi dan nutrisi ransum disajikan dalam Tabel 2. 
Tabel 1. Kandungan nutrisi bahan pakan (kering udara)

\begin{tabular}{|c|c|c|c|c|c|c|}
\hline Bahan Pakan & EM $^{\mathbf{a}}$ & PK & SK & LK & $\mathbf{C a}$ & $\mathbf{P}$ \\
\hline 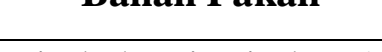 & (Kkal/kg) & & & $(\%)$ & & -- \\
\hline Limbah cair pindang* & $3.981,00^{\mathrm{b}}$ & 0,32 & 0,18 & 10,95 & 0,00 & 0,00 \\
\hline Jagung giling** & $2.829,42$ & 8,45 & 8,33 & 3,01 & 0,03 & 0,23 \\
\hline Konsentrat CP $144 * *$ & $2.500,00$ & 37,00 & 6,00 & 2,00 & 12,00 & 1,20 \\
\hline Bekatul** & $3.253,32$ & 12,50 & 16,70 & 14,34 & 0,32 & 1,70 \\
\hline
\end{tabular}

Sumber : *Hasil Analisis Laboratorium Terpadu UNDIP, 2016.

**Hasil Analisis Proksimat Laboratorium Ilmu Nutrisi Pakan, Fakultas Peternakan dan Pertanian, Universitas Diponegoro (2016)

${ }^{a}$ Hasil perhitungan 70\% dari Gross Energy (Schable, 2004)

${ }^{b}$ Perhitungan EM menggunakan rumus Balton (Siswohardjono, 1982) EM = 40,81 (0,87 (Protein kasar + 2,25 Lemak kasar + BETN) + 2,5)

Tabel 2. Kandungan nutrisi dan susunan ransum perlakuan

\begin{tabular}{lrrrr}
\hline \multirow{2}{*}{ Bahan Pakan } & \multicolumn{4}{c}{ Perlakuan } \\
\cline { 2 - 5 } & T0 & T1 & T2 & \multicolumn{1}{c}{ T3 } \\
\hline Limbah Cair Pindang & 0,00 & 2,50 & 5,00 & 7,50 \\
Jagung Kuning & 49,00 & 46,50 & 44,00 & 40,50 \\
Bekatul & 20,00 & 20,00 & 20,00 & 20,00 \\
Konsentrat & 31,00 & 31,00 & 31,00 & 32,00 \\
Total & 100,00 & 100,00 & 100,00 & 100,00 \\
\hline \multicolumn{1}{c}{ Kandungan Nutrisi } & \multicolumn{3}{c}{} \\
\hline EM (Kkal/kg) & 2812,08 & 2844,57 & 2877,06 & 2906,25 \\
PK (\%) & 18,11 & 17,91 & 17,70 & 17,79 \\
SK (\%) & 9,28 & 9,08 & 8,87 & 8,65 \\
LK (\%) & 4,96 & 5,16 & 5,36 & 5,55 \\
Ca (\%) & 3,80 & 3,80 & 3,80 & 3,91 \\
P (\%) & 0,82 & 0,82 & 0,81 & 0,82 \\
\hline Keteranganyyyyy
\end{tabular}

Keterangan : Hasil perhitungan excel berdasarkan kandungan bahan pakan pada Tabel 1.

Peralatan yang digunakan terdiri dari timbangan digital untuk menimbang ternak, timbangan kapasitas $50 \mathrm{~kg}$ untuk menimbang bahan pakan, timbangan digital dengan kapasitas $5 \mathrm{~kg}$ dengan ketelitian $1 \mathrm{~g}$ untuk menimbang itik, timbangan digital kapasitas $5 \mathrm{~kg}$ dengan ketelitian 0,0001 g untuk menimbang bobot lemak abdominal, kandang yang terdiri dari 20 petak, tempat pakan dan tempat minum, thermometer dan hygrometer, desinfektan, lampu 100 watt untuk penerangan dan untuk brooder, tirai plastik untuk melindungi kandang dari pengaruh cuaca, kamera digital untuk dokumentasi, alat tulis untuk mencatat dan kertas label sebagai penanda.
Peralatan bedah yang digunakan adalah pisau, nampan, dan kantong plastik. Penelitian dimulai dari DOD (Day Old Chicken) atau itik umur sartu hari dan dilaksanakan selama 8 minggu. Itik umur 1-14 hari diberi pakan komersial CP 511, pemberian pakan ransum perlakuan dimulai pada umur 15 hari hingga 45 hari dengan masa adaptasi 1 minggu. Frekuensi pemberian pakan pada pukul 06.00 WIB dan 16.00 WIB. Sisa pakan ditimbang setiap pagi hari. Konsumsi air minum dilakukan secara adlibitum. Pengukuran dan pencatatan suhu dan kelembaban pada mikroklimat dan makroklimat setiap jam 06.00, 12.00, 18.00 dan 24.00 . 
Rancangan dalam penelitian menggunakan rancangan acak lengkap (RAL) dengan 4 perlakuan dan 5 ulangan, sehingga jumlah total unit percobaan adalah 20 unit dengan setiap unit percobaan terdiri dari 6 ekor itik. Ransum perlakuan yang diberikan yakni :

T0: Ransum control (tanpa penggunaan limbah cair pemindangan ikan)

T1: Ransum dengan 2,5\% limbah cair pemindangan ikan

T2: Ransum dengan 5\% limbah cair pemindangan ikan

T3: Ransum dengan 7,5\% limbah cair pemindangan ikan

Parameter yang diamati adalah kadar lemak daging dan lemak abdominal serta kadar kolesterol daging. Pengambilan data dilakukan setelah pemotongan ternak. Pengambilan data kadar lemak daging diperoleh dengan mengambil sampel daging bagian dada dan paha dengan perbandingan 1:1 yakni dengan berat masing-masing $25 \mathrm{~g}$ kemudian dihaluskan dan dihomogenkan. Sampel diambil sebanyak $3 \mathrm{~g}$ dan dianalisis menggunakan analisis Soxhlet dan perhitungan lemak daging diperoleh menggunakan rumus :

Berat kering - Berat lemak ekstrak Berat sampel $\times 100 \%$

Persentase lemak abdominal didapat dengan menimbang berat lemak abdomen dan dibandingkan dengan bobot hidup dan dikali seratus persen.

Rumus perhitungan persentase lemak abdominal :

$\frac{\text { Berat lemak abdominal }}{\text { Bobot hidup }} \times 100 \%$

Pengukuran kadar kolesterol daging dilakukan dengan mengambil sampel daging bagian dada dan paha dengan berat masing-masing $25 \mathrm{~g}$ kemudian dihaluskan dan dihomogenkan. Sampel diambil sebanyak $5 \mathrm{~g}$ dan dianalisis menggunakan metode Enzymatic Cholesterol High Performance (CHODPAP KIT). Rumus perhitungan kadar kolesterol adalah :

konsentrasi standar x ( $\Delta$ absorban $)[\mathrm{mg} / 100 \mathrm{~g}]$

$$
\Delta \text { standar }
$$

Analisis data menggunakan analisis ragam dengan uji $\mathrm{F}$ pada $\mathrm{P} 0,05 \%$ dan dilanjutkan dengan Uji Jarak Berganda Duncan's apabila uji statistik berbeda nyata. Model persamaan yang digunakan

$$
Y i j=\mu+\alpha i+\varepsilon i j
$$

Keterangan :

Yij : Hasil Persentase ke-ij

$\mu \quad$ : Rata-rata pengamatan (nilai tengah umum)

ai : Pengaruh aditif dari perlakuan kei

cij : Galat perrcobaan dari perlakuan ke-i pada pengamatan ke-j

j : : 1, 2, 3, 4

\section{HASIL DAN PEMBAHASAN}

Rataan hasil penelitian pengaruh penggunaan limbah cair pemindangan ikan terhadap kadar lemak daging, persentase lemak abdominal dan kadar kolesterol daging itik hasil persilangan Mojosari Peking disajikan pada Tabel 3. 
Tabel 3. Pengaruh penggunaan limbah cair ikan terhadap kadar lemak daging, persentase lemak abdominal dan kadar kolesterol daging itik

\begin{tabular}{cccc}
\hline Perlakuan & $\begin{array}{c}\text { Kadar Lemak } \\
\text { Daging (\%) }\end{array}$ & $\begin{array}{c}\text { Persentase Lemak } \\
\text { Abdominal (\%) }\end{array}$ & $\begin{array}{c}\text { Kadar } \\
\text { Kolesterol } \\
\text { Daging } \\
\text { (mg/100g) }\end{array}$ \\
\hline T0 & 3,06 & 0,36 & 92,81 \\
T1 & 2,47 & 0,33 & 91,05 \\
T2 & 3,12 & 0,41 & 111,20 \\
T3 & 3,75 & 0,44 & 111,22 \\
\hline
\end{tabular}

Keterangan : Hasil analisis ragam terhadap setiap perlakuan menunjukkan hasil yang tidak berbeda nyata $(\mathrm{P}>0,05)$

\section{Kadar lemak daging}

Hasil analisis ragam menunjukkan bahwa penggunaan limbah cair pemindangan ikan dalam ransum tidak berpengaruh nyata $(\mathrm{P}>0,05)$ terhadap kadar lemak daging itik (Tabel 3.) pada perlakuan yang diberi ransum dengan limbah cair pemindangan ikan pada taraf $2,5 \%, 5 \%$ dan $7,5 \%$. Rata-rata persentase lemak daging berkisar antara $2,47 \%$ $3,75 \%$.

Tidak berbeda nyatanya persentase lemak daging itik menunjukkan bahwa pemberian limbah cair pemindangan ikan hingga taraf $7,5 \%$ tidak mampu menurunkan persentase lemak daging. Persentase lemak daging yang tidak berbeda nyata dapat disebabkan oleh kandungan energi dalam pakan. Lingga dkk. (2016) menyatakan bahwa lemak dalam daging berasal dari energi pakan yang berlebih yang disimpan dalam bentuk lemak. Ternak mengonsumsi pakan didasarkan pada kebutuhan energinya sehingga jika kebutuhan ternak sudah tercukupi ternak akan berhenti mengonsumsi pakan. Kandungan energi ransum penelitian sudah mencukupi kebutuhan itik. Kebutuhan energi itik fase starter umur $0-2$ minggu sebesar $2900 \mathrm{kkal} \mathrm{EM} / \mathrm{kg}$, fase grower umur 2 7 mingu $3000 \mathrm{kkal} \mathrm{EM/kg} \mathrm{(National}$ Research Council, 1994).

Persentase lemak daging tiap perlakuan tidak berbeda jauh. Faktor yang mempengaruhinya salah satunya adalah susunan ransum perlakuan yang digunakan dalam ialah isoenergi sehingga ternak memperoleh energi dari pakan relative sama. Selain itu, kandungan lemak karkas juga dapat dipengaruhi oleh persentase lemak abdominal. Menurut Leclercq and Witehead (1988), lemak lemak abdominal berkorelasi positif dengan lemak karkas yakni jika lemak abdomen meningkat maka lemak karkas juga meningkat. Hasil lemak abdomen dalam penelitian menunjukkan tidak berbeda nyata yang menyebabkan persentase lemak daging juga tidak berbeda nyata.

Kandungan lemak yang tinggi mempengaruhi perlemakan dalam tubuh. Jika kandungan lemak dalam ransum tinggi maka lemak akan segera disimpan dalam tubuh karena kecernaan lemak mencapai 90\%. Kandungan lemak dalam ransum masih berada dalam batasan kandungan lemak dalam ransum yakni rata-rata berkisar antara $4-5 \%$. Hal ini sesuai dengan pendapat Zainudin (2006) yang menyatakan bahwa batasan pemberian lemak dalam ransum unggas berkisar antara 4-7\%.

\section{Persentase lemak abdominal}

Rataan hasil persentase lemak abdominal tiap perlakuan tidak menunjukkan perbedaan yang signifikan $(\mathrm{P}>0,05)$ terhadap persentase lemak abdominal itik (Tabel 3.) pada perlakuan yang diberi ransum dengan limbah cair pemindangan ikan pada taraf 2,5\%,5\% dan $7,5 \%$. Rata-rata persentase lemak 
dagingyang diperoleh berkisar antara $0,33 \%-0,44 \%$. Hasil yang tidak berbeda nyata disebabkan oleh energi pakan yang dikonsumsi tidak berbeda nyata. Hal ini menyebabkan energi pakan tidak digunakan untuk pembentukan lemak. Menurut Deaton and Loft (1985), lemak abdomen dipengaruhi jumlah energi yang terkandung dalam ransum. Oktaviana dkk. (2010) menyatakan bahwa lemak abdominal terbentuk sebagai akibat dari kelebihan energi pakan yang dikonsumsi. Energi pakan dalam ransum penelitian sudah mencukupi ternak sehingga ternak akan mengonsumsi pakan sesuai kebutuhannya saja dan energi tidak digunakan untuk pembentukan lemak.

Lemak abdominal merupakan ikutan dari timbunan lemak tubuh. Menurut Fouad and El-Senousey (2014), hubungan deposit lemak abdomen sebagai akibat berkurangnya energi ransum yang dikonsumsi berkaitan dengan berkurangnya aktivitas enzim lipogenesis di hati antara lain enzim nicotinamideadenin dinukleotida phosphate-malat dehidrogenase, glukosa6-fosfat (G-6-PDH), 6-fosfoglukonat dehydrogenase dan enzim fatty acyd synthase (FAS). Peran enzim FAS jalur lipogenesis de novo di hati adalah menentukan kemampuan ternak untuk mensintesis lemak.

Rata-rata persentase lemak abdominal dari hasil penelitian lebih rendah dibandingkan dengan hasil penelitian Bintang dkk. (1997) yakni itik Mojosari, itik Tegal dan persilangan itik Mojosari Tegal memiliki persentase lemak abdominal sebesar 0,55-0,89\%.

\section{Kolesterol daging}

Kadar kolesterol pada hasil analisis ragam tidak menunjukkan perbedaan nyata $(\mathrm{P}>0,05)$ (Tabel 3.) pada perlakuan yang diberi ransum dengan limbah cair pemindangan ikan pada taraf 2,5\%,5\% dan 7,5\%. Rata-rata kadar kolesterol daging berkisar antara 91,05 mg/100g $111,22 \mathrm{mg} / 100 \mathrm{~g}$. Kadar kolesterol daging yang tidak berbeda nyata dapat disebabkan oleh taraf pemberian limbah cair pemindangan ikan hingga taraf 7,5\% masih rendah sehingga tidak mempengaruhi kadar kolesterol daging.

Kadar kolesterol daging yang yang tidak memperlihatkan perbedaan yang nyata dapat dipengaruhi oleh kandungan lemak tubuh. Kandungan lemak yang semakin meningkat akan menyebabkan kandungan kolesterol juga meningkat karena kolesterol merupakan bagian dari lemak (Devlin, 1993). Berdasarkan hasil penelitian, persentase lemak daging yang diperoleh tidak berbeda nyata. Menurut Santoso dkk. (2013), asam lemak omega 3 tidak mampu menurunkan kolesterol karena omega 3 tidak mampu membatasi enzim yang berperan dalam sintesis kolesterol yakni Hidroksi Metil Glutaril Asetil KoA (HMG KoA) reduktase sehingga belum mampu menghambat biosintesis kolesterol. Penelitian ini menunjukkan bahwa kandungan omega 3 dalam limbah cair pemindangan ikan rendah sehingga tidak mampu menekan biosintesis lemak.

\section{KESIMPULAN}

Penggunaan limbah cair pemindangan ikan hingga taraf $7,5 \%$ belum mampu menurunkan kadar lemak daging, persentase lemak abdominal dan kadar kolesterol daging itik hasil persilangan Mojosari Peking. Limbah pemindangan ikan ikan dapat dijadikan cairan untuk membasahai pakan sehingga dapat mengurangi pakan tercecer.

\section{DAFTAR PUSTAKA}

Bintang, I. A. K., M. Silalahi, T. Antawidjaja dan Y. C. Raharjo. 1997. Pengaruh berbagai tingkat kepadatan gizi ransum terhadap kinerja pertumbuhan itik jantan lokal dan silangannya. Jurnal Ilmu Ternak dan Veteriner, 2(4), 237241. 
Chashnidel, H., H. Moravej, A. Towhidi, F. Asadi and S. Zeinodini. 2010. Influence of different levels of n-3 supplemented (fish oil) diet on performance, carcass quality and fat status in broilers. African Journal of Biotechnology, 9(5), 687-691.

Deaton, J.W. and B.D. Lott. 1985. Age and dietary energy effect on broiler abdominal deposition, Poultry Science. 67, 966-967.

Devlin, M. T. 1993. Texbook of Biochemistry With Chemical Corre Latios. Third edition. Willey-Liss. United States of America pg : 438.

Direktorat Jenderal Peternakan dan Kesehatan Hewan. 2016. Data Populasi dan Produksi Peternakan di Indonesia. Direktoral Jenderal Peternakan dan Kesehatan Hewan Kementerian Pertanian RI.

Fouad AM, El-Senousey HK. 2014. Nutritional factors affecting abdominal fat deposition in poultry: A review. AsianAustralasian Journal Animal Science .27, 1057-1068.

Leclerq, B and C.C. Witehead. 1988. Leanness in Domestic Birds. The Institute Nasional de la Recherche Agronomique. London.

Lingga, F. H., Sulasmi, T. Armansyah, S. Aisyah, Ismail, B. Panjaitan dan Razali. 2016. Pengaruh pemberian ekstrak daun Bandotan (Ageratum conyzoides) terhadap berat karkas dan lemak abdominal ayam broiler. Jurnal Medika Veterinaria, 10(1), 23-26.

Montgomery. R. R. L. Dyrer, T.W. Conway dan A. A. Spector. 1993. Biokimia Suatu Pendekatan
Berorientasi kasus. Jilid 2. Terjemahan : M. Ismadi. Gadjah Mada University Press. Yogjakarta.

Oktaviana, D., Zuprizal dan E. Suryanto. 2010. Pengaruh penambahan ampas virgin coconut oil dalam ransum terhadap performans dan produksi karkas ayam broiler. Bul. Peternakan. 34, 159-164.

Santoso, A., N. Iriyanti dan T. Rahardjo S. 2013. Penggunaan pakan fungsional mengandung omega 3 , probiotik dan isolat antihistamin $\mathrm{N}_{3}$ terhadap kadar lemak dan kolesterol kuning telur ayam kampung. Jurnal Ilmu Peternakan, 1(3), 838-855.

Schable, P. J. 2004. Poultry feed and nutrition. Departement of poultry series, Michigan State University. East Lansing, Michigan. 198-198.

Zainuddin, D. 2006. Teknik Penyusunan Ransum dan Kebutuhan Gizi Ayam Lokal. Materi Pelatihan Teknologi Budidaya Ayam Lokal dan Itik. Kerjasama Dinas Peternakan Provinsi Jawa Barat dengan Balai Penelitian Ternak Bogor. Bogor. 